\title{
AGOSTINHO DE HIPONA E AS AMBIVALÊNCIAS DO SEU FILOSOFAR
}

\author{
AUGUSTINE OF HYPPO AND THE \\ AMBIVALENCES OF HIS PHILOSOPHY
}

Rogério Miranda de Almeida*

\begin{abstract}
RESUMO - Este texto tem como objetivo principal analisar algumas das ambiguidades que marcam a posição de Agostinho de Hipona com relação à chamada cultura pagã, em geral, e à filosofia grega em particular. Efetivamente, o autor das Confissões se situa em um meiotermo, que eu denomino pela expressão "o paradoxo do entre-dois", porquanto ele não abraça totalmente aquela posição que, a exemplo de Justino Mártir, equipara a sabedoria cristã à filosofia grega, nem tampouco reivindica aquela outra extremada, defendida por Tertuliano, que vê entre a "sabedoria cristã" e a "sabedoria pagã", ou entre fé e razão, um antagonismo ou um fosso intransponível. Nessa perspectiva do entre-dois, três questões principais serão examinadas: (a) a relação entre filosofia e religião cristã; (b) o problema dos "filósofos platônicos"; (c) os conceitos de reminiscência e memória.
\end{abstract}

PALAVRAS-CHAVE - Agostinho. Filosofia. Platão. Plotino. Memória. Entredois.

ABSTRACT - The main objective of this text is to analyze some of the ambiguities that characterize Augustine of Hippo's position regarding the so-called pagan culture in general and Greek philosophy in particular. As a matter of fact, the author of Confessions is situated in a mid-term, which I identify by the expression "the paradox of between", for he does not totally embrace the position of Justin Martyr, who identifies Christian wisdom with Greek philosophy, neither does he claim the other extreme position of Tertullian, who sees an antagonism or an insuperable gap between "Christian wisdom" and "pagan wisdom", or between faith and reason. In the perspective of this paradox, three major questions will be examined: (a) the relation between philosophy and Christian religion, (b) the problem of the "platonic philosophers", (c) the concepts of recollection and memory. KEYWORDS - Augustine, philosophy, Plato, Plotinus, memory, in between.

* Doutor em filosofia pela Universidade de Metz (França) e em teologia pela Universidade de Estrasburgo (França). Professor no Programa de Pós-Graduação em Filosofia da PUCPR, Campus Curitiba. E-mail: r.mirandaalmeida@gmail.com.

\begin{tabular}{|l|l|l|l|l|l|}
\hline Veritas & Porto Alegre & v. 57 & n. 2 & maio/ago. 2012 & p. 194-212 \\
\hline
\end{tabular}


Dentre as três principais tendências que marcaram a tradição filoófico-teológica ocidental, Agostinho de Hipona (354-430) se inscreve naquela que representa, por assim dizer, um intermediário, ou um entredois, com relação às outras duas tendências. Com efeito, se, de um lado, Justino Mártir (c. 100-165) equipara a filosofia grega à religião cristã, na medida em que ambas exprimem o Logos ou são, em última instância, modos diferentes de dizer ou de buscar a mesma verdade, de outro lado, Tertuliano (c. 155-c. 222) estabelece uma dicotomia ou antinomia irredutível entre a "sabedoria cristã" e a "sabedoria pagã". "O que tem a ver Atenas com Jerusalém?", interroga-se o apologeta no sétimo capítulo do Tratado da prescrição contra os heréticos. Se se possui a fé - enfatiza Tertuliano -, nada mais se deseja crer, pois começa-se justamente por crer que, para além da fé, nada mais existe que nos possa forçar a crer.

Essa tendência extrema, vemo-la mais uma vez reproduzida no século 11 com Pedro Damião (1007-1072), monge de Fonte Avellana, sagrado bispo de Óstia e depois nomeado cardeal da mesma cidade. Inimigo rancoroso da razão e da dialética, este conselheiro do Papa Gregório VII acusa a filosofia de ser uma invenção do diabo e sustenta - na obra intitulada $D e$ divina omnipotentia - que a ação de Deus não depende nem mesmo do princípio de não contradição. É também Pedro Damião que, a partir de uma explicação alegórica que fizera Jerônimo de uma passagem de $D t$ 21.10-13, está na origem da concepção medieval segundo a qual a filosofia é "serva da teologia" (ancilla theologiae). Não menos desprovido de uma linguagem chula e repleta de diatribes é Martinho Lutero (1483-1546), que chama a razão de prostituta, as universidades de antros de prostituição e vê entre a fé e a razão, ou entre a teologia e a filosofia, um fosso intransponível e uma oposição sem nenhuma possibilidade de conciliação.

Quanto a Justino, a filosofia é, pelo contrário, o único caminho que pode conduzir e unir a Deus, de sorte que não teriam existido nem platônicos, nem estoicos, nem peripatéticos, nem pitagóricos, caso não houvesse a Verdade (cf. Justino, 1995, p. 215)ํ. Ora, se todas as

1 Todavia, convém notar que Justino, ao empregar o termo "filosofia", ao invés de "teologia", queria evitar confundir a "sabedoria cristã" com a mitologia grega. Com efeito, no período clássico grego, a palavra "teologia", à diferença da "filosofia", era empregada para designar o estudo dos deuses ou dos mitos. Assim o pensa Platão, para quem a teologia remete ao canto e às narrativas dos poetas que, pela mitologia, fazem relevar os modelos divinos (cf. Platão, 2004, p. 154). Para Aristóteles, a "teologia" é uma das três disciplinas da filosofia teorética considerada a ciência por excelência, porquanto ela se ocupa do divino, presente na natureza imóvel e separado das realidades sublunares (cf. Aristóteles, 1986, p. 333). Já os estoicos distinguiam três tipos de teologia: a "teologia física" ou "natural", que pertence aos filósofos e se ocupa da natureza da divindade; a "teologia mítica", que é fabulada pelos poetas; e a "teologia política", que se move na esfera do poder civil e diz respeito aos sacerdotes 
religiões que dizem "sim" ao Logos, ou à Verdade, se equivalem, não se pode fugir à consequência segundo a qual nenhuma religião positiva é imprescindível. Certo, o que faz Justino distinguir a "sabedoria cristã" da "sabedoria grega" - assinalando àquela um papel de superioridade ou de excelência com relação a esta última - é o paradoxo da encarnação que se faz sobrelevar já no início do Prólogo do Evangelho segundo João. Efetivamente, afirmar que o Logos - que é universal, imutável, eterno se fez carne é introduzir uma ruptura ou uma descontinuidade no seio mesmo da racionalidade que, enquanto tal, é infensa a toda e qualquer ingerência ou miscibilidade entre o finito e o infinito, entre o particular e o universal, entre o temporal e o atemporal, entre o histórico e o a-histórico.

Mas, em que finalmente consiste a concepção filosófico-teológica de Agostinho, a qual, e a despeito das diferenças de perspectiva e de acento que as distinguem, tem mais de um ponto em comum com as concepções de Clemente de Alexandria, de Orígenes, de Anselmo de Aosta e Tomás de Aquino? De fato - e a julgar pelos seus escritos -, esses autores se colocam também em um meio-termo ou em uma posição intermediária entre aquelas duas visões extremas a que acima me referi. Todavia, dados os limites formais deste artigo - e visto que eu pretendo desenvolver essas questões em um estudo posterior -, ater-me-ei no momento às ambiguidades que marcaram a escrita agostiniana a partir de três questões principais: (a) a relação entre a filosofia e a religião cristã, (b) a influência do platonismo e/ou neoplatonismo sobre o seu pensamento, (c) a problemática da reminiscência e da memória.

\section{A filosofia, a religião cristã e o paradoxo do entre-dois}

$\mathrm{Na}$ verdade, o papel da filosofia vis-à-vis da teologia ou, mais exatamente, da religião cristã se apresenta, na obra de Agostinho, mais paradoxal do que uma primeira leitura poderia levar a imaginar. E esse paradoxo se faz ressaltar não somente nos últimos escritos, aqueles em que o bispo de Hipona - cada vez mais envolvido nas controvérsias teológicas - privilegiará a questão das relações entre a natureza, a graça, a providência e a liberdade, mas também nos primeiros escritos, aqueles produzidos entre 386 e 387 - durante o chamado "período de conversão" - e que se convencionaram designar pela expressão "diálogos

e aos cultos prestados ao Estado ou pelo Estado. Embora, no início da era cristã, Clemente de Alexandria e Orígenes se tenham servido desse termo para se referirem, respectivamente, à "doutrina da fé" e à "verdadeira doutrina sobre Deus e Jesus Cristo como salvador", ele receberá um status científico somente a partir do séc. 12, quando Pedro Abelardo designará com "teologia" a exposição racional e sistemática do conjunto das doutrinas da fé cristã. 
de Cassiciaco". Foi, de fato, nessa localidade que se desenrolou uma série de diálogos entre o próprio Agostinho, a sua mãe Mônica, o amigo Alípio, os discípulos Licêncio e Trigésio, o irmão Navígio, o filho Adeodato e mais dois primos ${ }^{2}$. Contudo, esse paradoxo ou essa ambivalência de Agostinho com relação à filosofia se deixa também verificar nas obras elaboradas depois de seu retorno à pátria, antes de sua ordenação presbiteral, em 391. Com efeito, terminada a estadia na Itália (383-388), durante a qual ele sofrera a influência de Ambrósio, em Milão, lera as Escrituras e se familiarizara com o pensamento neoplatônico, Agostinho continuará maturando e reelaborando aquelas questões cuja solução ele julgara poder encontrar no maniqueísmo: o mal e a liberdade. Ajunte-se, porém, que ele se ocupará igualmente do problema da linguagem e da música - de resto, a sua formação fora centrada na retórica, na filologia e na literatura -, assim como das relações entre a religião cristã e a filosofia.

Nessa perspectiva, em uma das primeiríssimas obras, $A$ vida feliz, composta em 386, é sublinhado o fato de que o pensamento, quando se dirige para Deus, adquire - mesmo em se tratando de pessoas incultas - o peso e o significado de um verdadeiro oráculo (cf. Agostinho, 2006, p. 283). No diálogo seguinte, intitulado $A$ ordem, Agostinho será mais explícito ainda ao falar do papel que desempenha a filosofia na esfera da fé. A filosofia - acentua o retor - não somente promove e fortalece a razão, mas também induz a não desprezar os mistérios da fé e, melhor ainda, ajuda a compreendê-los como devem ser compreendidos. Por conseguinte, a verdadeira e genuína filosofia tem a função não só de ensinar em que consiste o princípio não principiado de todas as coisas, mas também de mostrar a grandeza do intelecto que nele permanece e os benefícios que dele derivam para a salvação do gênero humano (cf. Agostinho, 2006, p. 389).

Esse apoio que busca a fé na razão, aspirando a ser por ela iluminada, ampliada e aprofundada, é um leitmotiv que percorre os escritos agostinianos - nomeadamente os do primeiro período - e que influenciará mais de um pensador medieval, em particular Anselmo de Aosta (10331109). Com efeito, o autor do posteriormente denominado "argumento ontológico" deixa claro, já no primeiro capítulo do Proslogion, que não procura compreender para crer, mas crê para compreender ("Neque enim quaero intelligere ut credam, sed credo ut intelligam"; cf. Anselmo, 2002, p. 315). É a fé indagando, buscando, meditando, querendo e esforçando-se por firmar-se e intensificar-se na e através da intelecção ("fides quaerens

Não se sabe ao certo se o antigo topônimo Cassiciacum, na Itália setentrional, região de Milão, se refere à localidade de Casciago, na atual província de Varese, ou àquela de Cassago, na província de Brianza. 
intellectum"). Assim, tanto Anselmo quanto, antes dele, Agostinho se reclamam da passagem de Isaías, segundo a qual: "A cabeça de Efraim é Samaria e a cabeça de Samaria é o filho de Romelias. Se não o crerdes, não vos mantereis firmes" (Is 7.9).

Ora, em Livre-arbítrio - obra que encetara no ano em que se preparava para deixar Roma (388), mas que só terminará bem depois do regresso à África (394-395) -, o autor das Confissões insiste na distinção entre o crer e o compreender, advertindo, ao mesmo tempo, sobre a necessidade de primeiramente se crer nas "grandes e divinas verdades" que se desejam entender. Essa é a razão pela qual ele recorre não somente ao versículo de Isaías, acima citado, mas também aos Evangelhos segundo João e Mateus. Com efeito, ao comentar a passagem "Buscai e achareis" (Mt 7.7), ele pondera que não se deve considerar "achado" aquilo que é crido sem ser conhecido; não se deve tampouco afirmar que alguém se torna apto a encontrar a Deus, sem antes ter crido naquilo que depois irá conhecer (cf. Agostinho, 2006, p. 971-973). Mas, já nos Solilóquios, composto em 387, é posta em relevo a seguinte explicação: "Por isso, procuro compreender aquilo que sei, e não aquilo que creio. Entretanto, é talvez correto afirmar que tudo aquilo que sabemos, também o cremos; mas não é correto afirmar que tudo aquilo que cremos, também o sabemos" (Agostinho, 2006, p. 485) $)^{3}$.

Curiosamente, no último livro que Agostinho escreveu como leigo - $A$ verdadeira religião (389-391) -, vemos surgir, já no início da obra, uma ambiguidade com relação à filosofia, na medida em que o retor assinala à religião uma função e uma ordem superiores àquelas que atribui à investigação filosófica. Convém, ademais, lembrar que a expressão "verdadeira religião" (vera religio) já se encontrava no Apologeticum, de Tertuliano, e na obra Divinae Institutiones, de Lactâncio. De um lado, portanto, Agostinho define a verdadeira religião como o caminho que conduz a uma vida boa e feliz e pelo qual se reconhece Deus como o Princípio de todas as coisas. De outro lado, porém, ele a considera como o modo mais evidente de se descobrir o erro daqueles povos idólatras, "cujos sábios, que chamamos filósofos, possuíam escolas contrastantes umas com as outras e templos comuns entre si" (Agostinho, 1997, p. 27). Mais incisivo ainda se mostrará o retor quando, depois de mencionar explicitamente os nomes de Sócrates e Platão - cuja filosofia ele conhecera através da tradução de uns dois diálogos e, indiretamente,

3 Esta passagem será reproduzida quase que literalmente no diálogo Do mestre (De magistro), composto em 389, onde Agostinho declara: "Portanto, aquilo que compreendo, também o creio; mas não compreendo tudo aquilo que creio. Sei tudo aquilo que compreendo, mas não sei tudo aquilo que creio" (Agostinho, 2006, p. 1741). 
através de Cícero e do que havia sido traduzido de Plotino e de Porfírio -, ele concluirá dizendo que aqueles filósofos não nasceram para demover os seus povos do prazer de venerar os ídolos, nem tampouco para conduzilos "ao verdadeiro culto do verdadeiro Deus" (Agostinho, 1997, p. 29). Não menos surpreendente é vê-lo afirmar, na mesma obra, que, ao entrar em um debate, é preferível ter o coração pleno da verdade que ter a boca repleta do nome de Platão (cf. Agostinho, 1997, p. 37). No entanto, logo em seguida - ao concluir esse longo discurso sobre as relações entre a religião cristã e a filosofia dos antigos gregos - o teólogo dirá que, se aqueles homens pudessem reviver e agir entre os cristãos, certamente descobririam a quem pertence a autoridade com a qual se pode vir em socorro dos homens e, "mudadas poucas palavras e expressões, tornarse-iam cristãos, como o fez a maior parte dos platônicos da nossa época e daquela que acabou de transcorrer" (Agostinho, 1997, p. 39).

Ora, no livro intitulado, A doutrina cristã - cuja redação se escalonara entre 396 e 426 -, Agostinho põe em destaque uma "grande questão" que Ambrósio de Milão teria resolvido. Trata-se, segundo o autor, da acusação levantada pelos leitores de Platão, segundo a qual todas as máximas de Cristo teriam sido hauridas nos livros do filósofo grego. Porém, o bispo de Hipona objeta que Ambrósio, após haver estudado a história das nações e descoberto que Platão, contemporâneo de Jeremias, fora ao Egito na mesma época em que lá também estivera o profeta, mostrou que é mais provável terem sido as Escrituras a haver influenciado Platão que, antes, ter sido o filósofo a havê-las inspirado. De resto, completa o autor das Confissões, nem mesmo Pitágoras, cujos discípulos teriam ensinado a teologia a Platão, existia antes que existissem as Escrituras. Portanto, conclui, é mais condizente com a verdade atribuir "às nossas Letras" o que de bom e de verdadeiro disseram os filósofos, do que atribuir a Platão as máximas que Cristo teria pronunciado. "Crê-lo possível seria o cúmulo da insensatez" (Agostinho, 1989, p. 199)4.

4 Na Cidade de Deus, Agostinho corrigirá o erro segundo o qual Platão teria sido contemporâneo do profeta Jeremias. Platão - diz o teólogo - nasceu cerca de cem anos depois que Jeremias escrevera as suas profecias (cf. Agostinho, 2000, p. 378). Todavia, esse novo cálculo, que Agostinho tomara de empréstimo a Eusébio de Cesareia, revela-se ele também inexato, pois, atendo-se ao testemunho do próprio Jeremias (Jr 25.3), a sua vocação teria ocorrido por volta do ano 627 a. C., enquanto que Platão viveu entre 427 e 348/347 a. C. De resto, o próprio Platão não faz nenhuma referência a uma possível estada no Egito ou na África, embora algumas observações desenvolvidas nas Leis sobre a arte, a música, a aritmética e os brinquedos das crianças egípcias deixem pressupor um conhecimento obtido de maneira direta. Ajunte-se ainda que a ideia segundo a qual a filosofia, e as ciências profanas em geral, tiveram origem nas Escrituras era uma ideia comum não só a Agostinho, mas também a outros Padres da Igreja, tais como Clemente de Alexandria, Orígenes e Tertuliano (cf., a esse respeito, Fortin, 1959, p. 169-172). 
Todavia, na Cidade de Deus, escrito elaborado entre 413 e 426, Agostinho dirá - logo no início do Livro VIII - que nenhum filósofo se aproximou mais dos cristãos do que Platão e seus discípulos. Para Platão, declara o teólogo africano: "O sábio é um imitador, um conhecedor e amante de Deus, e a participação em Deus lhe acarreta felicidade" (Agostinho, 2000, p. 367). Nesse mesmo Livro VIII, depois do encômio dirigido a Platão e aos platônicos, e após haver tecido toda uma crítica à teologia civil, ou política, assim como à teologia mítica, o autor da Cidade de Deus radicaliza de tal maneira a semelhança entre a filosofia platônica e a religião cristã, a ponto de declarar que não só as teologias mítica e civil devem ceder o lugar aos filósofos platônicos, porquanto foram eles "que ensinaram que o verdadeiro Deus é o autor das coisas, o iluminador da verdade e o dispensador da felicidade" (Agostinho, 2000, p. 369). Devem também ceder-lhes o lugar, completa o teólogo, aqueles outros filósofos que, com a mente voltada para o corpo e para as coisas sensíveis, passageiras, perecíveis, assinalaram à natureza princípios corporais, e não transcendentais (cf. Agostinho, 2000, p. 369). Quanto a Platão, a sua filosofia vê em Deus o verdadeiro e sumo bem, de sorte que o filósofo é também um amante de Deus. Consequentemente, "já que a filosofia tende para a felicidade, quem ama a Deus é feliz, porquanto nele coloca sua fruição" (Agostinho, 2000, p. 375).

Tão convergentes, portanto, se revelam essas duas sabedorias que Agostinho será levado a declarar, no Comentário ao Evangelho segundo João - série de homilias pronunciadas, provavelmente, a partir de 405 -, que nos livros dos filósofos se acham coisas análogas àquelas que serão expressas pelo próprio evangelista. Eles teriam vislumbrado, por exemplo, que Deus tem um único Filho, por meio do qual todas as coisas foram criadas (cf. Agostinho, 2005, p. 97). Imediatamente, porém, o teólogo emite a ressalva, segundo a qual aqueles filósofos não quiseram, na sua "soberba sapiência", agarrar-se à humildade de Cristo, isto é, àquela nave que os conduziria, seguros, ao porto entrevisto (cf. Agostinho, 2005, p. 97).

Essa apreciação ambivalente de Agostinho se manifesta igualmente no que tange à influência que exerceram os estoicos sobre o plano éticoepistemológico da tradição filosófica cristã. Assim, no Livro V da Cidade de Deus, ao comparar esses filósofos aos epicureus, o teólogo releva o fato de que os estoicos consideravam a virtude por ela mesma, isto é, como um fim no qual o homem encontraria a sua felicidade e o seu bem supremo. Inversamente, os epicureus tomavam a virtude como um meio para melhor usufruírem dos prazeres do corpo (voluptatis corporalis) - (cf. Agostinho, 2000, p. 257). Ora, no Livro VIII da mesma obra, o autor irá atacar não somente os epicureus, mas também os estoicos, porquanto 
- afirma ele - os pensadores da Stoá sustentavam que o fogo, isto é, um dos quatro elementos que compõem o universo visível, é dotado de vida, de sabedoria e da capacidade de construir o mundo e todas as coisas que ele encerra. Por conseguinte, conclui o teólogo, julgavam esses filósofos que o elemento ígneo fosse definitivamente um deus, melhor: "Os estoicos, e aqueles que se lhes assemelhavam, podiam representar somente aquilo que seus corações, ligados aos sentidos da carne, lhes permitiam fabular" (Agostinho, 2000, p. 369). É que, observa Agostinho, dentro de si mesmos tinham eles aquilo que não viam ou, para dizê-lo de outro modo, dentro de si mesmos imaginavam o que exteriormente haviam visto, mesmo se não o tivessem realmente visto. Mas, objeta o teólogo, aquilo que está diante de tal imaginação já não é corpo, mas um fantasma, uma semelhança (similitudo) de corpo. Já a faculdade pela qual o espírito vê essa semelhança não é nem corpo nem imagem de corpo, de sorte que aquilo por onde se percebe e se julga o que é belo ou disforme é mais perfeito que o próprio fantasma que é julgado. A consequência desse raciocínio não poderia ser outra: é a mente que se revela como o constitutivo essencial do homem e da alma racional e, enquanto tal, ela não pode ser um corpo, pois nem mesmo a imagem (similitudo) do corpo que é percebida e julgada pelo espírito como sendo um corpo não é, propriamente falando, um corpo. Donde a conclusão: "A mente não é nem terra, nem água, nem ar, nem fogo, que são os quatro corpos considerados como sendo os quatro elementos pelos quais vemos estruturado o mundo corpóreo" (Agostinho, 2000, p. 370). E poderíamos ajuntar, resumindo: as coisas externas, percebidas pelos sentidos, são dotadas de configuração, de extensão e materialidade; as coisas fabuladas pela imaginação são dotadas de extensão e configuração visíveis, mas não de materialidade; já o espírito, ou a mente, se apresenta como uma função ou uma faculdade que percebe, que raciocina, que distingue e julga. Ela é, portanto, uma coisa pensante.

Do ponto de vista ético, é lícito, pois, afirmar que a inclinação de Agostinho - com todas as ambiguidades que esta inclinação pode comportar - vis-à-vis dos estoicos, de Platão e do que ele chama os "filósofos platônicos" consiste na ênfase que estes pensadores deram à virtude enquanto virtude, ou enquanto uma excelência que tem sua finalidade em si própria. Já no plano ontológico e epistemológico, é a visão platônica ou neoplatônica dos dois mundos que encontrou sua preferência no teólogo africano: de um lado, o mundo sensível e, portanto, mutável, caduco, não consistente e não autossuficiente; de outro lado, porém, o mundo espiritual e, por conseguinte, inascível, imarcescível, imutável e eterno. Mas, quem, finalmente, são esses "filósofos platônicos" aos quais se refere o autor das Confissóes? 


\section{Agostinho e os "filósofos platônicos"}

Com efeito, nas Confissões, que ele redigira entre 397 e 401, deparamonos com uma afirmação que tem suscitado mais interrogações que esclarecimentos: "Por intermédio de um homem cheio de orgulho desmesurado, tu (Deus) me proveste de alguns livros dos filósofos platônicos traduzidos do grego para o latim" (Agostinho, 2002, p. 223). Certo, nas mesmas Confissões, o autor menciona que o tradutor dos livros platônicos era Mário Vitorino (cf. Agostinho, 2002, p. 249). Todavia, as traduções dos autores neoplatônicos que fizera esse mestre de retórica, originário da África, convertido ao cristianismo e fundador de uma escola em Roma no tempo do imperador Constantino (337-361), não chegaram até nós. Supõe-se, contudo, que ele traduzira alguns tratados essenciais das Enéadas e alguns escritos de Porfírio, discípulo de Plotino.

Com o termo, "platônicos" (platonicorum), teria Agostinho querido compreender toda a tradição platônica que o precedera? O certo é que, além de Plotino e Porfírio, ele também menciona Jâmblico, Apuleio, Hermes Trismegisto e, no Contra os acadêmicos - primeiro dos diálogos de Cassicíaco -, já se encontra uma análise das temáticas fundamentais da Academia de Platão e uma crítica às tendências céticas que nela se introduziram através dos nomes - que Agostinho cita explicitamente - de Arquesilau de Pitane, Carnéades de Cirene, Filão de Larissa e Antíoco de Ascalona. Mas, se a questão de saber quem são propriamente esses "filósofos platônicos" permaneceu, até agora, uma questão insolúvel, o outro problema sobre o qual se têm debruçado os estudiosos é o de decidir a quem, afinal de contas, tocaria a prioridade dada por Agostinho a esses pensadores: se a Plotino ou a Porfírio. Verdade é que já na obra A vida feliz ele confessa haver lido "pouquíssimos livros de Plotino", os quais, no entanto, parecem tê-lo inflamado de tal maneira que ele não hesita em afirmar que eles manifestam uma verdadeira concordância com o que já haviam dito os autores sacros (cf. Agostinho, 2006, p. 237). Aqui, Agostinho pensa especificamente no apóstolo Paulo e no evangelista João. Mas, já no Contra os acadêmicos, esse entusiasmo se fizera igualmente assomar, porquanto, após haver sobrelevado "a ilustre palavra de Platão que, em filosofia, é a mais pura e a mais límpida", o autor assevera que essa palavra retornou em Plotino. Melhor ainda: "Este filósofo, verdadeiramente platônico, foi de tal modo julgado semelhante ao mestre que se chegou a pensar que fossem contemporâneos. Todavia, entre os dois intercorre um grande lapso de tempo, de sorte que é lícito ver no segundo uma revivescência do primeiro" (Agostinho, 2006, p. 199). Não obstante isso, na Cidade de Deus, depois de ter enaltecido Marcos Terêncio Varrão (116-27 a. C.) como "o mais douto dentre os romanos" 
(doctissimus Romanorum), Agostinho conclui dizendo que Porfírio é "o mais douto dentre os filósofos" (doctissimus philosophorum) - (cf. Agostinho, 2000, p. 1068).

Este e outros encômios dirigidos a Porfírio levaram recentemente alguns estudiosos - Hadot, Dörrie, Madec - a atribuírem o primado ao discípulo de Plotino quanto a uma influência neoplatônica sobre o pensamento agostiniano. Uma das razões evocadas consiste em que, tendo sido as Enéadas redigidas em um estilo denso, cerrado, repleto de pressupostos e desdobramentos conceituais, dificilmente delas se poderiam extrair teses explícitas, cujos enunciados haviam sido, justamente, concebidos para um círculo restrito de iniciados nas doutrinas plotinianas. Quanto a Porfírio - argumentam esses estudiosos -, o seu estilo é amplo, direto, discursivo e claramente ordenado, o que não acarretaria problemas para uma tradução em latim. O próprio Agostinho confessa que não era apto a ler textos em língua grega - pelo menos no primeiro período de sua formação -, de sorte que as obras neoplatônicas que lhe eram familiares devem ter sido tão-somente aquelas traduzidas pelos pensadores neoplatônicos do círculo de Milão. Sem embargo, algumas questões mais específicas reenviam mais diretamente a fontes plotinianas, o que leva a crer que o autor das Confissões deva ter conhecido os tratados essenciais sobre o belo, assim como aqueles sobre as três hipóstases originárias, a unidade do mundo inteligível e a providência ${ }^{5}$. O problema, porém, é que não se sabe ao certo quais eram precisamente as traduções dos tratados das Enéadas que se achavam então disponíveis, inclusive aquelas realizadas pelo mestre de retórica, Mário Vitorino. É, contudo, provável que tenham sido somente essas que Agostinho tenha conhecido. Por outro lado, não se deve excluir a hipótese segundo a qual aquelas doutrinas poderiam ter sido hauridas a partir de obras porfirianas, na medida em que nelas se encontram vestígios de formulações típicas de Porfírio quanto a uma teologia negativa.

Efetivamente, a teologia apofática - convém lembrar - encontra-se tanto em Dionísio Areopagita quanto em Agostinho, e ambos são tributários da tradição neoplatônica que os precedera de imediato. Segundo essa teologia, Deus, enquanto summa essentia, está acima e além de toda forma e de toda categoria. De modo que tempo e espaço, essência e existência, ato e potência, e até mesmo o conceito de substância, não podem ser predicados de Deus. Não obstante isso, há também, segundo Agostinho, uma maneira positiva, catafática, de se

Nas Enéadas (Plotino, 2004), essas doutrinas se acham respectivamente nos tratados I 6 (1); V 1 (10); VI 4-5 (22-23); III 2-3 (47-48). Para um resumo das questões relativas às fontes do platonismo, ou neoplatonismo, de Agostinho, cf. Horn (2005, p. 25-27). 
referir a Deus, na medida em que ele é a unidade de todas as formas e o princípio de toda beleza. Assim, todas as ideias, todas as essências ou todos os princípios das coisas se acham presentes na mente de Deus, independentemente do fato de elas existirem ou não na realidade. Esta dialética do negativo e do positivo se revela, nos escritos agostinianos, através das metáforas do amor: eros e agape, ou caritas. Isso quer dizer que, na medida em que as realidades sensíveis - o corpo, a carne e tudo aquilo que vive - se movem do baixo para o alto, aspirando, desejando e ansiando a serem assimiladas e apreendidas pelas realidades mais altas, temos presente a dinâmica do eros. Quando, porém, o Logos se faz carne, ou quando Deus se move em direção do homem na caritas, assumindo-o e elevando-o, pela participação, até o divino, estamos diante do agape ${ }^{6}$. É o que se lê no Livro VII das Confissões, onde, no capítulo 9, parágrafo 14, Agostinho equipara as intuições desenvolvidas pelos "livros platônicos" àquelas que se encontram nas Escrituras e, mais especificamente, no Prólogo do Evangelho Segundo João e na Epístola aos Filipenses, de Paulo. Com relação a esta última, ele afirma, citando textualmente os versículos do segundo capítulo:

Naqueles livros eu descobri, decerto sob múltiplas e variadas expressões, que o Filho não considerou o ser igual a Deus como algo a que se apegar ciosamente, ele que lhe era da mesma natureza, mas esvaziou-se a si mesmo, e assumiu a condição de servo, tomando a semelhança humana. $E$, achado em figura de homem, humilhou-se e foi obediente até a morte, e morte de cruz. Por isso Deus o exaltou dos mortos e lhe deu um nome que está acima de todo nome. (Agostinho, 2002, p. 225)7.

Surpreendente, porém, é ver Agostinho - logo antes de citar as palavras de Paulo - constatar que a revelação joanina, "o Verbo se fez carne e habitou entre nós", não se encontrava nos livros platônicos, que, no entanto, ele equiparara aos escritos sacros. Mais surpreendente ainda é vê-lo declarar, no parágrafo 13 do mesmo capítulo 9:

Ali [nos livros dos "filósofos platônicos"] eu achei escrito, se não com as mesmas palavras, mas com um sentido absolutamente igual e com o apoio de muitas e variadas razões, que no princípio era o Verbo e o Verbo estava com Deus e o Verbo era Deus. No princípio, ele estava com Deus. Tudo foi feito por meio dele e sem ele nada foi feito. O que foi feito nele era a vida, e a vida era a luz dos homens; e a luz brilha nas trevas, mas as trevas não a apreenderam. (Agostinho, 2002, p. 223) ${ }^{8}$.

6 Cf., a este respeito, Tillich (1968, p. 115-116).

7 Está em itálicos a citação que faz Agostinho das Escrituras (Carta aos Filipenses 2.6-9).

8 Está em itálicos a citação que faz Agostinho das Escrituras (Prólogo do Evangelho Segundo João 1.1-5). 
Ora, tanto em Plotino quanto em Platão - e na tradição clássica grega em geral - não se encontra o conceito de criação, pelo menos na maneira como ele seria desenvolvido pela concepção cristã de uma criação do nada. É bem verdade que, nesta passagem, Agostinho não acrescenta aos versículos do Evangelho a noção de uma creatio ex nihilo. Verdade também é que, no Timeu, já se acha presente a ideia de uma criação do mundo, embora não se trate propriamente de uma criação, mas de uma formação, ou de uma plasmação que opera o Demiurgo a partir dos paradigmas contemplados. Donde poder-se concluir: o ponto essencial de divergência entre a concepção platônica e a concepção agostiniana de Deus reside justamente na doutrina da encarnação. Nesse sentido, Agostinho é tributário de toda a tradição cristã que o precedera, tanto daquela do Novo Testamento quanto daquela que desenvolverão os Padres Apostólicos e os Apologetas dos séculos 2-3. Como vimos no início dessas reflexões, o que realmente faz Justino Mártir distinguir a "sabedoria cristã" da "sabedoria grega" é precisamente o paradoxo da encarnação, pelo qual o Logos - que é atemporal e universal - irrompe no seio mesmo do tempo, do particular, do contingente, do finito. Mas, Agostinho também se destaca da tradição platônica na medida em que desloca o acento da doutrina da reminiscência para uma análise da memória centrada sobre o indivíduo, a sensibilidade e os mecanismos de defesa que o sujeito, inconscientemente, constrói.

\section{A memória, a vontade e a reminiscência}

De fato, no Livro X das Confissões - sobre a memória - Agostinho antecipa muitas das intuições que serão desenvolvidas e elaboradas pela psicanálise a partir do final do século $19^{9}$. Aqui, o autor chama a atenção para o caráter dinâmico, ativo, seletivo, que caracteriza a mente na sua capacidade de se recordar e de esquecer, de ruminar e, portanto, de digerir o que lhe apraz e refutar o que, pelo contrário, só lhe causaria desprazer. Ora, conquanto se sirva de metáforas e figuras que reenviam a um espaço capaz de receber e guardar as experiências do passado - a memória como um "ventre", um "seio", um "campo", um "esconderijo", uma "imensa caverna", um "amplo e infinito santuário" -, o filósofo não a considera como um lugar ou um receptáculo puramente passivo,

9 Ao fazer tal afirmação, não pretendo, de forma alguma, sugerir que Freud não fez senão explicitar o que Agostinho já descobrira quinze séculos antes do nascimento da psicanálise. De resto, o inventor da psicanálise não leu Agostinho e não tinha familiaridade com o seu pensamento. Ao bispo de Hipona ele faz tão-somente breves e ocasionais alusões sem, todavia, entrar ou deter-se nas suas teorias. Para uma análise dos antecedentes agostinianos com relação à psicanálise, cf. Almeida (2011). 
apto a recolher e a tornar disponíveis as impressões que afetaram os sentidos. Não! Para ele, a memória se apresenta como uma grande força, uma grande potência, uma magna vis. É uma força impossível de ser apreendida e sondada em todas as suas vicissitudes e sinuosidades, justamente porque é uma magna vis (cf. Agostinho, 2002, p. 347). Embora, ou precisamente porque é uma faculdade do espírito e, dessa forma, se encontra intrínseca e essencialmente ligada à natureza do sujeito, este jamais poderá compreendê-la totalmente, porquanto algo lhe está continuamente a escapar, a resistir, a elidir, a subtrair, a transformar-se.

É que, em Agostinho, memória e vontade caminham pari passu, melhor, a memória é uma das manifestações, ou uma das expressões, da vontade. "A vontade está em todas as inclinações, ou antes, estas não são senão atos da vontade"; é o que ele acentuará da maneira mais veemente na Cidade de Deus (Agostinho, 2000, p. 694). Afinal de contas - insiste o teólogo -, o que são o "desejo" (cupiditas) e a "alegria" (laetitia) senão movimentos e inclinações que se dirigem, ou convergem, para os objetos que queremos? (cf. Agostinho, 2000, p. 694). Na Trindade, obra redigida entre 399 e 426, ele irá mais uma vez enfatizar o papel que representa a vontade na sua dinâmica de fazer a mente trazer à tona as imagens que jazem latentes, adormecidas, sopitadas, nos esconderijos da memória. É que, mesmo após haver desaparecido a forma sob a qual os objetos se haviam apresentado aos sentidos, quedará potencialmente na memória uma semelhança, ou um fantasma, para onde a vontade, mais uma vez, poderá lançar um olhar e, assim, reavivá-los ou, mais exatamente, re-enformá-los. Certo, se a forma desaparecesse de maneira absoluta, seguir-se-ia também um esquecimento absoluto, de sorte que toda e qualquer tentativa de recordação se tornaria igualmente impossível. Em outros termos, se o olhar daquele que evoca tal recordação não fosse informado a respeito desta realidade que virtualmente subjaz na memória, tampouco se poderia realizar a visão que, agora, caracteriza o pensamento propriamente dito. Contudo, a união destas duas realidades - da imagem que resta em suspensão na memória e de sua expressão no olhar daquele que evoca tal recordação - se dá de tal modo que se tem a impressão de se tratar de uma única e mesma realidade. Convém, todavia, precisar que, quando o olhar do pensamento se desvencilha daquela imagem e cessa de considerá-la, desaparece igualmente a forma impressa na visão interior, de sorte que, ao lançar o olhar para outra recordação, surge ao mesmo tempo uma nova forma, origem de um novo pensamento. Não obstante isso, completa Agostinho, perdura na memória aquilo que fora abandonado, mas não abolido, porquanto o olhar, quando quiser, voltar-se-á novamente para lá, estabelecendo assim 
um novo vínculo e, por assim dizer, uma nova unidade com o princípio enformante (cf. Agostinho, 1998, p. 337-338).

Como se pode deduzir, embora se trate de dois movimentos da vontade - um que move os sentidos na direção dos objetos do mundo exterior e outro que faz a mente lançar um olhar para as formas ou as imagens que se acham depositadas no interior -, um não tem primazia sobre o outro, no sentido em que um seria cronologicamente anterior ao outro. Não! Esses dois movimentos são simultâneos, concomitantes, tautócronos. Existe aqui distinção, mas não separação entre dois planos, como se, de um lado, houvesse um mundo exterior e, de outro, um mundo interior. $\mathrm{O}$ que Agostinho deixa realmente pressupor é a existência de uma dinâmica que inter-corre entre esses dois mundos e pela qual a vontade se manifesta justamente como um liame, um vínculo, ou um entre-dois, de modo que nem mesmo a razão saberá se se trata de um corpo externo, realmente percebido (videtur), ou de um corpo interno e, portanto, pensado (cogitetur). Produz-se, assim, uma tríada formada pela memória, a visão interna e a vontade que, enquanto princípio de toda ação, une uma potência à outra, fazendo uma incluir-se na outra ou uma passar pela outra (cf. Agostinho, 1998, p. 336).

Ora, como eu lembrei no final da seção anterior, Agostinho se destaca também da tradição platônica na medida em que ele desloca o acento da doutrina da reminiscência para uma análise da memória centrada sobre o indivíduo e os mecanismos de defesa que caracterizam o sujeito da fala e, portanto, da falta, da hiância e da clivagem que se inter-põe entre o pedido e o objeto desejado. Certo, nos primeiros escritos, o filósofo tendia a considerar a memória em estreita ligação não somente com a doutrina da iluminação interior, mas também com a teoria platônica e/ou neoplatônica do conhecimento, para a qual os conteúdos já se acham aprioristicamente dados no sujeito que indaga. Assim, no diálogo intitulado A ordem, Agostinho coloca na boca de um dos interlocutores, Licêncio, um discurso cujos argumentos ele assegura já haver anteriormente desenvolvido em sua presença. A interrogação gira então em torno de saber se a memória é imprescindível ao sábio, ao que Licêncio responderá negativamente ajuntando, ao mesmo tempo, que o sábio já possui e conserva interiormente todos os conceitos de que necessita. Não precisamos do auxílio da memória - acrescenta - nem mesmo para a percepção dos objetos que se encontram ao nosso redor: "O sábio tem diante dos olhos interiores do intelecto todas as coisas, porquanto ele vê de modo fixo e imutável o próprio Deus, no qual estão todas as coisas que o intelecto vê e possui" (Agostinho, 2006, p. 373). Por conseguinte, não se trata de uma recordação no sentido próprio, dinâmico e individual do termo, mas de uma reminiscência, que se 
situa no plano mítico e platônico de um relembrar-se que transcende, preexiste e sobrevive ao próprio sujeito. Com efeito, no Mênon e em outros diálogos posteriores - o Fédon, a República, o Fedro -, Platão reconduz toda a nossa capacidade de conhecer a verdade a um estado anterior a essa existência temporal em que o indivíduo, convivendo com os deuses, experienciava uma visão direta e imediata das realidades que lhe eram dadas contemplar.

Certo, Agostinho não abandona - nos escritos posteriores - a ideia de um conhecimento a priori, porquanto esse pertence intrínseca e radicalmente ao seu método fundamental da interiorização, ou da iluminação interior. Eis a razão pela qual, no mesmo Livro $\mathrm{X}$ das Confissões, capítulo 11, ele acentua: a aprendizagem das noções que obtemos sem recorrer às imagens que se dão pelos sentidos, mas que vemos diretamente dentro de nós, não é outra coisa senão uma espécie de unificação que opera o pensamento a partir de elementos que se encontram esparsos e escondidos na memória. Trata-se, pois, de um trabalho que efetua a reflexão através do qual os elementos, que antes se achavam dispersos e negligenciados nos labirintos da memória, se mantêm, por assim dizer, ao alcance da mão e se oferecem às considerações que tece o espírito. No entanto, costuma-se dizer - completa Agostinho - que nós aprendemos e conhecemos essas noções, mas na verdade nós as reconhecemos, as redescobrimos, as reencontramos e as reinventamos (cf. Agostinho, 2002, p. 351). O mesmo se pode também afirmar das relações e das inumeráveis leis que regem a aritmética e a geometria, nas quais não se acha impresso nenhum vestígio proveniente dos sentidos corporais, pois elas não são dotadas nem de cor, nem de voz, nem de cheiro, nem de coisas que se degustam ou se apalpam (cf. Agostinho, 2002, p. 351).

Todavia, um pouco antes, ao falar das imagens que se encontram adormecidas nos secretos meandros da memória, Agostinho havia ponderado que ninguém saberia dizer como se formam tais imagens, embora "sejam visíveis os sentidos que as captam e as colocam no nosso interno" e embora seja sabido que todas elas entram pelas respectivas portas dos sentidos (cf. Agostinho, 2002, p. 345). Por conseguinte, não se poderia discorrer sobre as alturas das montanhas, as ondas do mar, as torrentes dos rios, a circunferência do oceano e as órbitas dos astros sem, antes, tê-las visto com seus próprios olhos ou ter ouvido alguém delas falar. Não obstante, objeta o filósofo: "Eu não as absorvi, quando as vi com meus olhos, nem se acham essas coisas reais depositadas em mim, mas as suas imagens. Ademais, eu conheço os sentidos do corpo a partir dos quais cada uma dessas imagens foi impressa em mim" (Agostinho, 2002, p. 347. Itálicos meus). 
Na obra $A$ verdadeira religião, Agostinho se havia mostrado ainda mais explícito ao analisar a relação que se opera entre a memória e a força da fantasia na sua capacidade de ampliar, recriar e multiplicar as imagens percebidas no passado. Assim: "Não existe nada de corpóreo que, tendo sido visto uma única vez, não possa ser imaginado inúmeras outras vezes ou que, tendo sido visto num espaço limitado, não possa, com a mesma potência imaginativa, ser dilatado ao infinito" (Agostinho, 1997, p. 83). É que, segundo o filósofo, cada um só pode conhecer através de seus próprios estados afetivos. Melhor: todos sabem pela experiência que a "alma" (anima) pode mudar no tempo, mas não no espaço. Quanto aos produtos da imaginação, estes não são senão figuras extraídas da "espécie do corpo" (specie corporis), que se formam justamente a partir e através dos órgãos dos sentidos. Eis a razão pela qual, pondera Agostinho, é fácil confiá-las à memória tais como elas foram recebidas ou então, graças ao poder criativo da fantasia, dividi-las, multiplicá-las, coligi-las, ampliá-las, ordená-las, modificá-las ou plasmá-las ao seu bel prazer. Difícil, porém, conclui o filósofo, é elidi-las e delas desvencilhar-se quando se procura a verdade (cf. Agostinho, 1997, p. 53). Isso é paradoxal ao extremo, na medida em que não existe outro caminho, não existe outra porta, não existe outra ponte para se aceder à verdade senão, justamente, aquelas que oferece o mundo da sensibilidade. Donde a constatação ambivalente, ambígua, ineludível e inelutável de Agostinho: "É facílimo detestar a carne, mas é dificílimo não conhecer segundo a carne" (Agostinho, 1997, p. 83).

Embora, portanto, seja o método do conhecimento agostiniano um método essencialmente a priori - no sentido em que a alma é dotada de uma pré-disposição e de um poder unificador das imagens que encerra a memória a partir dos sentidos -, Agostinho se manterá cada vez mais refratário a todo e qualquer conhecimento que pressupusesse uma reminiscência em termos míticos e/ou platônicos. Ocorre que isso implicaria a eternidade e, logo, a co-eternidade da alma vis-à-vis de Deus. A alma ou, mais exatamente, o espírito tem por certo a potência de evocar, organizar e unificar aprioristicamente o conhecimento que jaz adormecido nos esconderijos da memória, mas essa faculdade lhe fora impressa no ato mesmo de sua criação. A ambivalência agostiniana com relação à teoria platônica do conhecimento consiste precisamente nisso: apesar de seu fascínio por essa teoria, ele não poderia aceitá-la na sua integralidade, na medida mesma em que ela viria pôr em xeque o conceito de criação tal como este fora elaborado pela doutrina cristã de uma creatio ex nihilo. Assim, à diferença dos estoicos - para quem as razões seminais existem desde toda a eternidade -, à diferença também da tradição platônica, para a qual a alma preexiste e sobrevive ao próprio 
indivíduo, Agostinho irá justamente acentuar o caráter gratuito e contínuo da criação e - quando se trata da teoria do conhecimento - a dinâmica do rememorar e do esquecer, do ruminar e do recalcar, do transformar e do recriar.

\section{Conclusão}

O pensamento agostiniano vis-à-vis da filosofia em geral, e da filosofia grega - platônica, neoplatônica e estoica - em particular, se revela paradoxal na medida mesma em que ele se coloca em um meio termo, ou em um entre-dois relativamente àquelas duas posições extremas a que eu acenei no início destas reflexões. Efetivamente, o teólogo africano não equipara pura e simplesmente a "sabedoria cristã" à "sabedoria pagã" como já o fizera Justino Mártir - nem tampouco vê um fosso intransponível separando essas duas sabedorias, como já o fizera Tertuliano e, depois de Agostinho, o farão Pedro Damião, Lutero e, nos tempos modernos, Pascal, Kierkegaard e Karl Barth.

Convém, todavia, ter presente que as ambiguidades que marcam a posição de Agostinho face à cultura em geral e à filosofia em particular já apontam para as vicissitudes e as sinuosidades que pontilharam a sua própria trajetória pessoal e a sua evolução intelectual. Com efeito, o desenvolvimento do pensamento agostiniano - além da impressão que lhe causaram as leituras de Plotino e Porfírio e a descoberta das Escrituras durante o chamado período de conversão - se deu basicamente a partir da influência da filosofia grega clássica e da cultura latina. Quanto à primeira influência, de caráter platônico-estoico - mas um platonismo e um estoicismo que o teólogo conheceu essencialmente através dos escritos de Cícero -, ela se revela, além das questões que eu evoquei ao longo deste estudo, através daquelas outras relativas à providência, à necessidade e à predeterminação tal como a conceberam os estoicos com relação às razões seminais. À diferença dos estoicos, porém, Agostinho se serviu do conceito de criação e da ideia de um governo do mundo a partir do próprio Deus. Seria, porém, mais exato afirmar que esta problemática encontrou repercussão naquilo mesmo que Agostinho já possuía como intuição e visão do mundo em geral. Quanto à segunda influência, o autor das Confissóes foi sobremodo tocado por aquilo que a cultura romana possuía de mais característico: a literatura, o direito e uma concepção pragmática do homem centrada sobre a liberdade e a individualidade. Efetivamente, foi no direito romano que, pela primeira vez, surgiu a categoria de pessoa jurídica ou de indivíduo portador de direitos e deveres vis-à-vis de uma comunidade política. Essa categoria era praticamente ausente do universo clássico grego. Nesse, o bem e a 
prosperidade do indivíduo estavam em função do bem e da prosperidade da polis, e não o inverso. É nessa perspectiva que vemos Aristóteles declarar, já no início da Ética a Nicômaco, que o bem individual e o bem da polis se equivalem. Todavia, o Estagirita vê neste último uma tarefa manifestamente mais digna de ser apreendida e salvaguardada, porquanto esse tipo de bem - mais belo e mais divino - é aplicado a cidades ou a nações. Não esqueçamos, todavia, que Agostinho era um exímio conhecedor da literatura, da história e do direito romano, de cuja terminologia ele frequentemente se serve para elaborar a sua teologia da graça, da predestinação e da vontade. Ele está, portanto, dividido entre dois mundos: de um lado, o mundo grego - em que predominam as noções de destino, de fatalidade, de providência e predeterminação -, de outro lado, porém, o mundo latino, cujas criações essenciais se exprimem através das ideias de liberdade, de individualidade, de autonomia e autodeterminação.

Ora, as intuições e descobertas que elabora e desenvolve o teólogo africano ao longo de seu texto - texto entendido como espaço de resistência e, ao mesmo tempo, de passagem pela qual se desdobra o simbólico do real - são elas próprias manifestações de um traçado centrífugo, que aponta continuamente para uma significação que jamais se dá, ou que não se dá senão de maneira múltipla, fragmentária, lacunar. É o que eu denomino pela expressão "o paradoxo da escrita". Uma escrita que não cessa de fazer-se e de refazer-se, de plasmar-se e de remodelar-se, de interpretar-se e reinterpretar-se. Eis a razão pela qual Agostinho, ao ler e escrever as relações entre a "sabedoria cristã" e a "sabedoria pagã", está constantemente a oscilar entre um pólo e outro. Ao mesmo tempo em que se mostrava fascinado pela visão platônica ou neoplatônica de uma divisão bipartida do mundo - de um lado, o mundo das realidades sensíveis e, portanto, caducas, efêmeras e perecíveis, e de outro, o mundo das essências inteligíveis, imutáveis, eternas e divinas -, ele era também impressionado pelo paradoxo da encarnação do Logos e da criação ex nihilo. De resto, as diferenças essenciais entre a mentalidade grega e a mentalidade semítica residem justamente em que aquela privilegiava o conceito de logos - um logos atemporal e a-histórico - assim como as categorias de visão intuitiva da alma e de polis, enquanto que a mentalidade semítica dava o primado às noções de povo, de história e de palavra, mas uma palavra que se manifesta fundamentalmente através de eventos historicamente específicos, tais como o Êxodo, a revelação de Iahweh no Sinai, na tradição profética, etc. Quanto à sua teoria do conhecimento e, especialmente, à sua doutrina da iluminação interior, Agostinho tende fundamentalmente para um saber a priori que manifesta a capacidade unificadora e organizadora do 
espírito. Todavia, essa faculdade da alma ele coloca no plano da criação e do governo do mundo, que emana da lei divina. De resto, enquanto retor e músico, não podia passar-lhe despercebida a problemática que suscitam a voz, a palavra, a memória, a vontade, o desejo e, em suma, a linguagem.

$\mathrm{Na}$ verdade, esse paradoxo do entre-dois que atravessa o texto agostiniano na sua tentativa de apreender um significado que jamais se dá de maneira definitiva; esse vai-e-vem da significação que se revela recalcitrante a toda maestria e a todo domínio do discurso é característico da própria experiência da escrita, ou do texto, pois o que está em jogo nessa dinâmica do dizer e do desdizer é a própria tensão do desejo ou, para empregar um termo peculiar a Agostinho, é a própria tensão da vontade na sua infindável e sempre recomeçada satisfação.

\section{Referências}

AGOSTINHO, S. Tutti i dialoghi. Milano: Bompiani, 2006. . La città di Dio. Roma: Città Nuova, 2000. . Commento al Vangelo di Giovanni. Roma: Città Nuova, 2005. . Le confessioni. Torino: Einaudi, 2002. . La dottrina cristiana. Milano: Paoline, 1989. . La Trinità. Roma: Città Nuova, 1998. . La vera religione. Milano: Rusconi, 1997.

ALMEIDA, R. M. de. "Do recordar e do esquecer: a questão da memória em Agostinho, Nietzsche e Freud". In: Revista Filosofia Unisinos, 12 (2011): 3, p. 253-264.

ANSELMO DE AOSTA. Monologio e Proslogio. Milano: Bompiani, 2002.

ARISTÓTELES. La métaphysique. Paris: Vrin, 1986, 2 v.

FORTIN, E. L. Christianisme et culture philosophique au cinquième siècle. La querelle de l'âme humaine en Occident. Paris: Études Augstiniennes, 1959.

HORN, Ch. Sant'Agostino. Bologna: Il Mulino, 2005.

JUSTINO. Apologie. Milano: Bompiani, 1995.

PLATÃO. La République. Paris: GF Flammarion, 2004.

PLOTINO. Enneadi. Milano: Bompiani, 2004.

TERTULIANO. Traité de la prescription contre les hérétiques. Paris: Cerf, 1957.

TILLICH, P. A History of Christian Thought. New York: Touchstone, 1968.

Recebido em 12/02/2012.

Aprovado para publicação em 27/07/2012. 